\title{
Story-telling as memorialisation: Suffering, resilience and victim identities
}

OÑATI SOCiO-Legal SeRIES Volume 10, Issue 3 (2020), 535-543: Practices of MEMORIALIZATION AND THE PROCESS OF SOCIAL RECONSTRUCTION

DOI LINK: HTTPS://DOI.ORG/10.35295/OSLS.IISL/0000-0000-0000-1122

RECEIVED 28 NOVEMBER 2018, ACCEPTED 07 FEBRUARY 2020

\author{
SIMON T. GREEN* (iD) \\ KATHERINE KONDOR* \\ ALICIA KIDD*
}

\section{Abstract}

Is there a relationship between story-telling and memorialisation in the construction of victim identities? This paper seeks to examine these questions and shed light on the cultural dynamics of victimisation with reference to examples from sociological theories of late modernity and empirical research with people who selfidentify as victims. Using examples from recent biographic interviews with an asylum seeker fleeing conflict in Gaza and two Hungarian radical right activists, the argument will be that victim identities are constructed and reconstructed through the development of personal and mediatised narratives about suffering and resilience.

\section{Key words}

Victims; narrative; late modernity; Hungary; Gaza; story-telling

\footnotetext{
We would like to thank the editors of this special edition, Gema Varona Martínez and Martin Hoondert for inviting us to contribute and we would also like to thank the anonymous reviewers for the journal who offered very constructive feedback that has helped us improve this piece of writing. We would also like to acknowledge the EU COST Action (CA18121) that funds the research network Simon Green participates in called: Cultures of Victimology: understanding processes of victimization across Europe. And we are very grateful to the British Academy and Leverhulme Trust (SG161060) who funded his project: "Giving voice" to Victims: a strengths-based investigation into victim identities. Most importantly, we would like to give our unreserved thanks and gratitude to the research participants on all our projects that have informed and inspired the ideas in this article.

* Associate Dean for Research, Reader in Criminology, Faculty of Arts, Cultures and Education. University of Hull, HU6 7RX, UK. Email address: S.T.Green@hull.ac.uk

* Research Associate, School of Social Sciences and Humanities, Loughborough University, Epinal Way, Loughborough LE11 3TU, UK. Email address: K.A.Kondor@lboro.ac.uk

* Postdoctoral Research Assistant, Wilberforce Institute, University of Hull, HU6 7RX, UK. Email address: Alicia.Kidd@hull.ac.uk
} 


\section{Resumen}

¿Existe alguna relación entre la narración y la memoria en la construcción de las identidades de víctima? Este artículo pretende analizar esas cuestiones y arrojar luz sobre las dinámicas culturales de victimización, haciendo referencia a ejemplos de teorías sociológicas de la modernidad tardía y a investigaciones empíricas con personas que se identifican a sí mismas como víctimas. Utilizando ejemplos de entrevistas biográficas recientes con un solicitante de asilo que huía del conflicto de Gaza y con dos activistas húngaros de la derecha radical, argumentamos que las identidades de víctima se construyen y reconstruyen mediante el desarrollo de narrativas personales y mediatizadas sobre sufrimiento y resiliencia.

\section{Palabras clave}

Víctimas; narrativa; modernidad tardía; Hungría; Gaza; narración de historias 


\section{Table of contents}

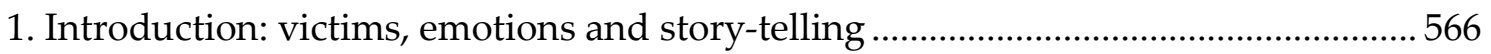

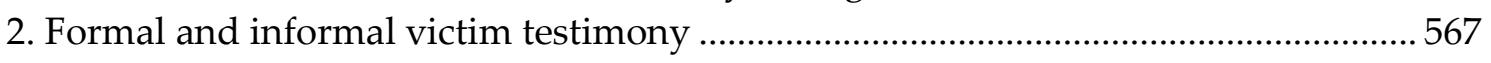

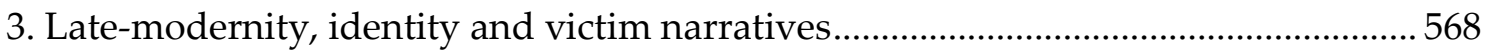

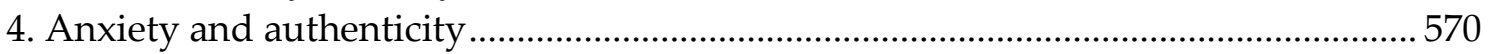

5. Identity construction and agency in story-telling: examples

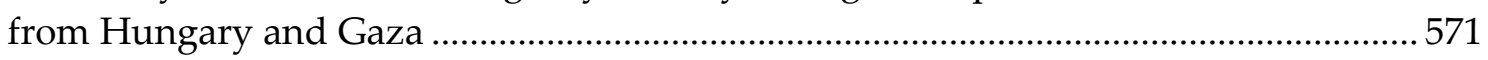

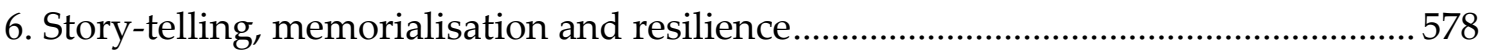

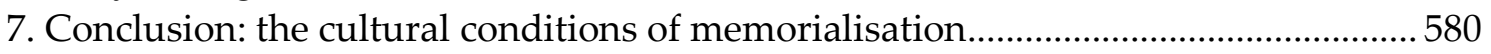

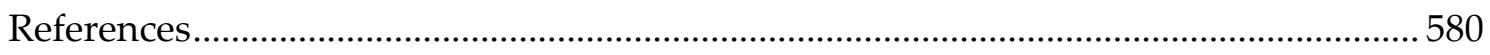




\section{Introduction: victims, emotions and story-telling}

Traditionally, memorialisation is understood in terms of ceremonies, statues or structures intended to remind us of historical events that ended in tragedy or sacrifice. New forms of memorialisation such as roadside, virtual and body art have also emerged though it has been argued the process of memorialisation has been underresearched in comparison to the forms in which memorialisation takes place (Holloway et al. 2018). Whatever their form, rituals and ceremonies of remembrance, commemoration and memorialisation are usually evoked to preserve our collective memory of past losses and provide a space or place in which communities can come together to remember profound events that give meaning to our lives (Gensburger and Lefranc 2020). Our contention is that the ways in which memorialisation takes place have changed. This change is found in the way we connect to each other and develop our sense of self-identity. This change will be explained in terms of a cultural transformation that should not underestimated in the context of memorialisation. The symbolic meaning attributed to memorialisation is derived from the culture in which it is located and social scientists have argued that we are witnessing a shift in cultural conditions from modernity to postmodernity, placing us in a period of late modernity. The cultural conditions of late-modernity have changed how we relate to ourselves and each other. We shall contend that this change extends to include processes and practices of memorialisation. In the context of victimisation following large-scale human rights violations, both the meaning ad practice of how victims memorialise what has happened to them has changed. This change allows victims to develop new forms of self-identity through which they find resilience by telling their stories of harm and suffering.

In particular, the cultural importance of raw emotion following an atrocity has become more and more salient as instant outpourings are immediately captured and reproduced for a mass audience. These emotions then spill out beyond those directly affected into public demonstrations, victim campaigns, newspaper headlines, transitional justice, dark tourism and victim testimonies (Peris 2005, Cuéllar 2013, McGarry and Walklate 2015). Think 3.7 million people marching through Paris after the Charlie Hebdo attack. Think the \#MeToo Twitter phenomenon regarding sexual harassment in the workplace. Think public outpourings of grief following the death of Princess Diana. As David Garland puts it:

The victim is every victim, she could be you or related to you. This personalizing trope, repeated endlessly on television news and documentaries, represents the crime victim as the real life, 'it could-be-you' metonym for the problem of personal security. And in so doing, it shifts the debate away from the instrumental reasoning of crime control analysis towards the visceral emotions of identification and righteous indignation. (Garland 2001, p. 144)

Within this context we are particularly interested in victim testimonies as a new form of memorialisation. These forums include, but are not limited to, criminal justice contexts such as restorative justice encounters, victim impact statements and victim "champions" or "ambassadors". However, we are just as interested in a growing body of less formalised testimonies that can be found in books that loosely fall into the "true crime" genre (or perhaps, more accurately an emerging "true victim" genre) as well as online books of remembrance, blogs, vlogs, TV and radio serialisations and a host of 
charitable and third sector websites, campaigns and interventions. There is no succinct written method of capturing the full range or style of victim testimonies and we see little value in a prescriptive definition. The montage found below gives a snapshot of what we're referring to:

\section{IMAGE 1}

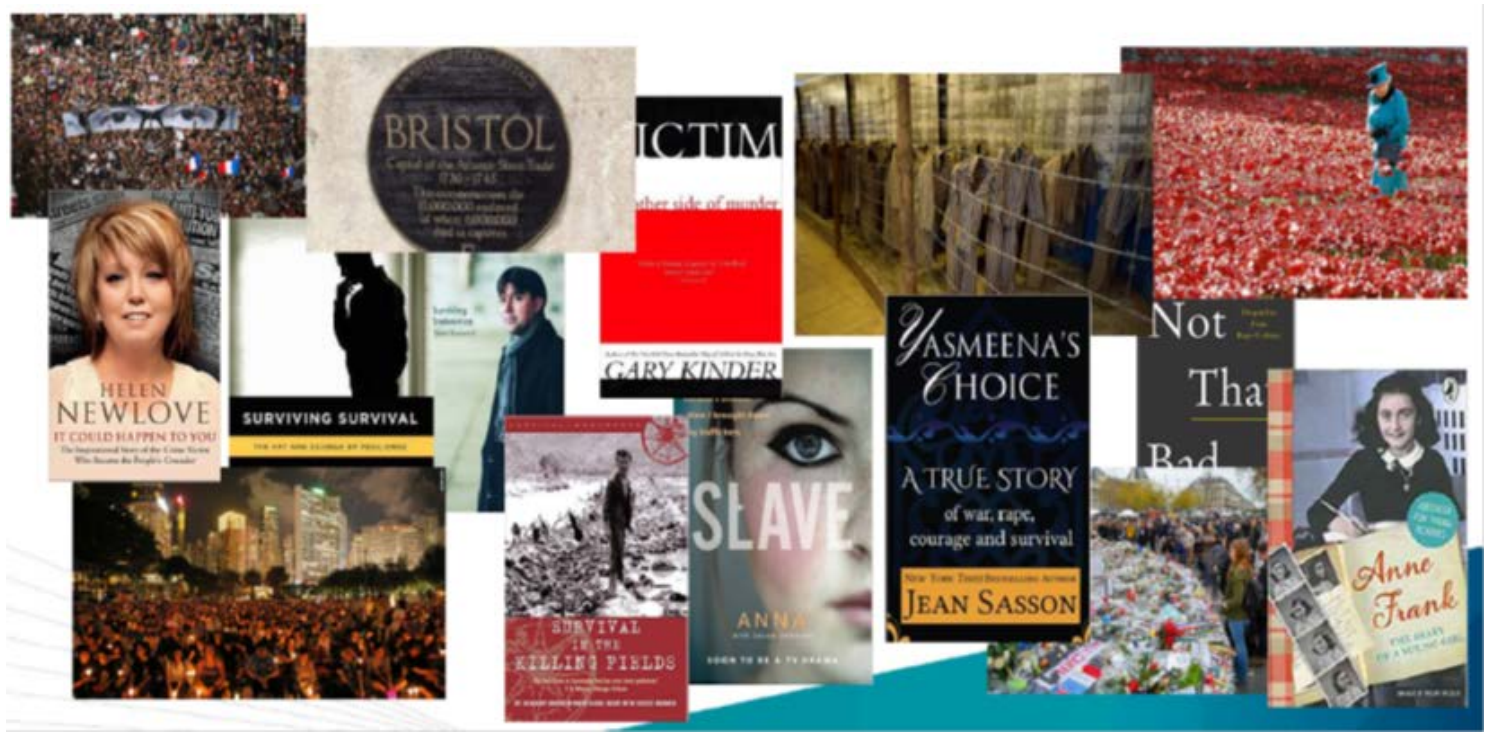

IMAGE 1. A montage of victim story-telling texts and images.

These images aim to provide a visceral representation of the different ways in which victim testimonies are captured and how they can shape our individual and collective sense of identity. Our goal is to chart the cultural conditions that shape these testimonies and seek to understand the value story-telling has for victims. To do this we shall draw on two separate case studies from two different research projects to illustrate how victim narratives provide the basis for resilience through the reconstruction of identity.

\section{Formal and informal victim testimony}

Beginning in the late 1960s and 1970s a growing realisation about the marginalisation of the victim within the criminal justice system emerges (Shapland et al. 1985, Mawby and Walkate 1994). This realisation leads to persistent attempts to give the victims of crime a new voice in the penal process. Whether extra-legal in the form of support and services, or procedural in the form of state and offender compensation, victim impact statement, vulnerable witness provision or restorative justice, these changes begin to reintroduce emotions into the penal realm (Green 2011, Barbot and Dodier 2014, McGarry and Walklate 2015, Gatti 2017). Whilst driven by a growing victims' lobby that argued justice was not being delivered for crime victims, these reforms also begin to shift the contours of how justice works. Alongside the state who prosecutes on behalf of the victim and the defendant who is accused of a crime, the victim now also steps. The introduction of crime victims in the penal decision-making process reintroduces those directly affected by the crime and, in particular, all of their feelings and frustrations, back into a system that had been designed to exclude emotion from the delivery of justice. De Haan and Loader (2002) have pointed to a number of ways in which emotions have become more central to the delivery of justice concluding that 
emotions have become "inescapably implicated in both the 'volatile and contradictory' nature of late-modern penality" (de Haan and Loader 2002, p. 247).

Hence the symbolic power of victimisation is intrinsically connected to media portrayals of crime and justice that depicts both real and fictional accounts of when the criminal justice system fails victims, and which invasively thrusts crime and its awful consequences into the homes and consciences of everyone. For Garland (2000, 2001) these expressive and emotive conditions are strongly associated with the conditions of late-modernity from which they arise. In a similar vein, Karstedt (2002) explores what she refers to as the emotionalisation of the law. Like Garland (2000) she also sees this trend as in keeping with the conditions of late-modernity and explains emotionalisation in terms of authentic assertions of self-identity that underscore individual autonomy and self-representation.

Karstedt (2002) considers the impact of these conditions on the way in which the penal process functions. Whilst she acknowledges the emotional context in which crime and criminal justice has always occurred, she argues that over the last decade or so there has been a noticeable increase in the emotional content of public discourses about crime and the introduction of punishments that "are explicitly based on - or designed to arouse - emotions" (Karstedt 2002, p. 301). Drawing Garland (2000) and Karstedt (2002) together, a picture begins to emerge of the cultural conditions that heighten the symbolic power of the victim and introduce emotionalism into the penal process. It is therefore perhaps unsurprising that virtually all of the arenas in which emotionalism has crept into penal policy have been predominantly victim-centred. Victim impact statements, restorative justice, vulnerable witness and victim programmes in court and a Victims' Commissioner all resonate strongly with both the increasing symbolic significance afforded to crime victims and the direction in which our cultural sympathies lie.

\section{Late-modernity, identity and victim narratives}

If the meaning and value of victim testimonies are shaped by cultural conditions, it is important to understand these conditions. Late modernity is usually understood as a phase between modernity and postmodernity. Modernity is usually associated with the shift from traditional, non-industrial and predominantly rural society to industrialised, urbanised and predominantly capitalist society. Closely linked with the ideas of Karl Marx (1861/1907), Emile Durkheim (1893/1964) and Max Weber (19045/1976), modernity represents the advent of rationality and the age of science and truth. According to Kumar (1978), features of modernity include urbanisation, industrialisation, democratisation, secularisation, rationalisation and bureaucratisation. These characteristics are seen to have developed from the Middle-Ages, before reaching fruition at the end of the Enlightenment period with the democratic revolution in France and the capitalist economic revolution in England. At the other end of the scale, postmodernity refers to the social, cultural and ideological conditions that replace those associated with modernity. Unlike modernity, post-modernity asserts the end of the scientific pursuit of rationality with its emphasis on discovering truth and achieving progress. Instead, post-modernity emphasises fragmentation and fluidity, without absolute values or universal governing laws. Hence, post-modernity is pluralistic, with many competing explanations and understandings of the world. 
Across the canon of social theory two of the most significant contributions to late modernity have come from Anthony Giddens (1990, 1991) and Ulrich Beck (1992, 1994). Giddens (1992) uses either the term "high" modernity or "late" modernity whilst Beck (1992, 1994) prefers "reflexive" modernity or "second" modernity. Both demonstrate a concern with the increasing insecurity and risk associated with mediating existence in contemporary society. A corresponding body of French social theory explores the decline of tradition and solidary and the growth of individualism and identity (eg. Dubet 2002, de Gaulejac and Legrand 2008, Martuccelli 2010) and taken together represent an explanatory framework from which to understand the growing cultural significance of victim narratives. Reflexive modernity is a state of mind in which the social agent increasingly mediates and navigates through the institutions and values of the social world as well as a more introspective reflection on the self and personal identity (Lash 1994). In this context, victim testimonies provide one way in which people reflect on, and navigate through the complexities of late modern existence. Part of this existence is an increasing shift into new spaces beyond the physical, in which social bonds are formed.

Giddens' (1990, 1991) work develops with what he refers to as "self-identity". He argues that one of the main characteristics of late-modernity is self-reflexivity, a condition whereby individuals continuously consider and reconsider their sense of self-identity. In pre-modern society, the institutions of family, community or church effectively proscribed identity. Yet in late-modernity this proscription is all but gone; each person now unencumbered from the shackles of tradition is now able to choose, change and reflect on the nature of their own identity:

The narrative of self-identity has to be shaped, altered and reflexively sustained in relation to rapidly changing circumstances of social life, on a local and global scale. The individual must integrate information deriving from a diversity of mediated experiences with local involvements in such a way as to connect future projects with past experiences in a reasonably coherent fashion. Only if the person is able to develop an inner authenticity - a framework of basic trust by means of which the lifespan can be understood as a unity against the backdrop of the shifting social events - can this be attained. A reflexively ordered narrative of self-identity provides the means of giving coherence to the finite lifespan, given changing external circumstances. (Giddens 1991, p. 215)

This continuous process of self-reflection is a consequence of living in a "posttraditional" society (Giddens 1994) where insecurity and risk become ongoing causes of anxiety. For Giddens (1991) these are essentially psychic and existential anxieties that he describes as ontological insecurities whereby a person becomes unhinged from biographical reference points which allow them to construct a narrative for themselves that provides them with a sense of emotional or psychic stability in an unpredictable and constantly changing world. Hence the conditions of late-modernity lead individuals to continuously create, recreate and reflect on their self-identity in a world that is itself reflexively ordered and liable to unpredictable change. The late-modern world is therefore a world in which the ability to personally construct and maintain an identity is crucial to survival.

The construction of "reflexive biographies" is used by both Giddens $(1991,1992)$ and Beck $(1992,1994)$ to denote the complicated path individuals must tread to create 
identity in this insecure and unpredictable world. This (re)construction of victim narratives and the associated sense of belonging and purpose that accompanies them is equally well-developed in a parallel literature on trauma and recovery. Similarly, Fassin and Rechtman (2009), Fassin (2014) and Wieviorka (2009) provide a compelling articulation of how victim testimony and victim suffering have grown in cultural and political importance and how victim trauma is differentially distributed across the moral economies of contemporary Western societies. Fassin and Rechtman's (2009) analysis of victim testimonies provides a critical analysis of the cultural hierarchy of trauma, whilst Wieviorka's (2009) articulation of the symbolic significance of victims in his treatise on the social and political representation of violence demonstrates the relationship between trauma, violence and victimhood.

Exploring how victims reshape their lives in the aftermath of violence and suffering this literature corroborates the cultural perspectives we are using as a theoretical framework to analyse the construction of victim identities (for good examples see: Antze and Lambek 1996, Skultans 1998, Brison 2002, Barbot and Dodier 2014, Herman 2015, Lefranc 2015, Gatti 2017, Garapon and Denouveaux 2019). For victims of human rights violations this insecurity therefore operates at both the structural and the personal levels - mutually reinforcing insecurity and driving the need for control. The narrative is consequently of even more significance to victims as they effectively experience a "double-whammy" of insecurity: an increasingly unstable social structure and some level of interpersonal injury (or at the very least a perception of injury). Of course, unstable social structures do not necessarily come from the conditions of late modernity and can just as easily emerge for conflict zones or social unrest. But either way, the effect is the same - victims feel extremely insecure and storytelling becomes an important part of reconstructing events that allows victims to exercise a degree of control over what has happened to them and connect with others who may have experienced similar hardships.

\section{Anxiety and authenticity}

Emotions and emotionalism are increasingly vested in a wide range of social interactions that are as transient as they are powerful. With all the fragile insecurities of late-modernity, emotions are elevated to the status of authenticity: one of the few remaining benchmarks of genuineness. The stronger, the purer, the more "from the heart" the emotion is, the more profound the sincerity and the greater the authenticity of the individual. From intoxicating romance to wailing grief through to blinding rage, the social world is increasingly invested with a level of emotional outpouring hitherto unknown. Whether it's sat on the sofa with Oprah, histrionics in the Love Island villa or tabloid campaigns to "out the pedo", emotions have become very public. If authenticity is achieved by emotional openness, such displays can be understood as part of a cultural practice of reaching out to others; the louder and stronger the emotion, the greater the need for self-identity and security. Thus emotional openness becomes the basis for connecting with others in an increasingly fluid and reflexive world. Evidence of this phenomenon can be gleaned across the social world. As Morgan and Averill $(2008,158)$ argue:

Whereas once, for example, people typically derived identity from clear cut religious and class expectations, now people more often define who they are in relation to 
'inner' needs and capacities, looking inward for markers of 'authentic being' that may let them know themselves.

How is an authentic self-identity generated? For Giddens (1991) one of the main consequences of late-modernity is the basis on which trust is established in a world where community and kinship networks are in decline. In such a world Giddens (1991) argues that personal trust is achieved by developing intimate relationships with friends and lovers. In an environment increasingly devoid of stable social institutions, trust is achieved through mutual openness and self-disclosure rather than pre-existing social networks. Intimacy is therefore achieved through an ongoing process of selfenquiry and self-discovery with other people. This is the basis of what Giddens (1991) refers to as the pure relationship, developed in relation to internalised emotional desires and personal connections. This pure relationship forms an important part of the search for an authentic self-identity as it provides defence against external threats and the capacity to connect with abstract notions of trust which are essential to survival in the late-modern world. Authenticity is therefore derived through emotions that are culturally understood as proxies for honesty and openness. These purely emotional and very intimate connections become central to the search for ontological security.

In a similar vein, Furedi (2004) discusses emotions and authenticity in the therapy culture of late-modern society and Aslama and Pantti (2008) outline the recent popularity of reality television in relation to the ongoing search to authentically know oneself. Greer (2004) explores the relationship between media reportage and coverage and the emotional outpourings of grief when a child goes missing or is murdered. Highly reminiscent of the public reaction to the death of Princess Diana, Greer (2004) argues that it is the conditions of late-modernity that create the emotional urge for people to come together to publicly share their grief:

Amid widespread ontological insecurity, individual life histories are structured, shaped, and made sense of within the frames of reference provided, to a significant degree, by mass media, to the extent that a sense of shared (popular) culture generates 'imagined community'. (Greer 2004, p. 110)

This sense of belonging is intimately connected to the development of authentic narratives that allow people to connect to one another. Anxiety about insecurity and instability is managed through a continuous process of reflexive creation and recreation of self-identity which then allows the individual to connect to the past and present by constructing an authentic self-identity that is true to oneself whilst also being able to adapt to an ever-changing social world. One of the core features of latemodernity is ontological insecurity and the ongoing task of building a self-identity that provides a measure of control and composure in conditions that constantly buffet the self in the eddies of a social and cultural malaise that is simultaneously liberating and deeply threatening (Giddens 1990, 1991).

\section{Identity construction and agency in story-telling: examples from Hungary and Gaza}

The discussion so far has sought to locate victim narratives within their cultural context. What this demonstrates is that story-telling has become an increasingly important tool for constructing self-identity and emotionally reaching out to others to 
generate a sense of belonging. Consequently, the cultural salience of victim narratives has changed and grown. This, we have argued, is because the victim is caught in a crucible of insecurity due to a combination of cultural conditions and personal violation. Furthermore, the growth of new technologies and mass media communications provides hitherto unknown opportunities to share stories of harm and suffering. These stories afford victims the opportunity to define their experiences on their own terms. In some situations this is overtly constructing their own interpretations of victimisation, whilst in others it is demonstrating personal courage or virtue in the face of adversity.

Whilst we have alluded to the breadth and depth of victim narratives now being told in a myriad of different ways, nearly all of these present a methodological problem as a source of 'evidence' to substantiate the point we are making. The problem is that these accounts have already been carefully constructed either by victims or by a third party (e.g. editor/publisher) to represent experiences in a particular way. Of course, this reconstruction is exactly our point, but it does leave us two steps removed from the victim, and as examples these texts lack credibility. Instead, we shall draw on two examples from our own empirical research with people who self-define as victims. We think both of these examples illustrate very effectively how people either construct themselves as victims or how they construct their victim stories to demonstrate agency and control over the circumstances in which they find themselves. Both interviews are anonymous and went through rigorous ethical approval processes at two separate British universities in 2016 and 2017. All research participants citied in this article gave their informed consent to use quotes from their interviews in published work. It is not possible to give details of where interviews took place or with whom, as this information could be used to identify one or more of the research participants.

Both of the following examples have been taken from independent research projects that nevertheless share a common theme with non-criminal forms of conflict and violence. The Hungarian interviews are from a comparative project investigating radical right political membership and the Gaza interview from a project exploring vulnerability to contemporary slavery for people fleeing conflict zones. They are intended as illustrative of our argument as both participants identify a sense of victimhood in their narrative, which in turn shapes their self-identity, purpose and resilience to external threats.

Example one: Hungarian nationalists. Memorialisation plays an important role in identity formation through victimisation in groups, through collective memory formation. This can occur in any group with a common goal and collective identity, even in those groups which cannot traditionally be considered as victimised. Here, collective identity can be defined considering the perception of group boundaries and singularity (Jasper 1997); it is "an act of the imagination" that can stir "people to action by arousing feelings of solidarity" with other group members (Jasper and McGarry 2015, 1). Collective identity considers a sense of togetherness among group members that can be "anchored in real or imagined shared attributes and experiences" (Snow 2001, p. 2213).

Collective action organisations often perceive themselves as victims in order to justify their cause; of course, it is a question as to whether the perceived victimisation is justified and a conscious part of the organisation's collective identity. In certain cases, a 
group may feel victimised and use memorialisation of this victimisation in their collective identity formation and to support their cause. This, curiously, can occur not only in persecuted groups, but among those who persecute others; indeed, this phenomenon is often found in radical right and nationalist rhetoric. Common in the radical right groups is obfuscated collective memory, used to justify their victimhood and thereby justify their actions and attitudes. For example, this can often be seen in anti-Muslim rhetoric of many radical right organisations, displaying white Europeans and Americans as victims of terrorism and the influence of Islam.

An excellent example of how members of the radical right have structured their values and identity in terms of victimisation is found in the Hungarian radical right, evidenced by empirical data from recent interviews. Interviews mainly focused on group membership, namely pathways to membership and membership maintenance, but also examined identity-formation, both individual and group. Semi-structured indepth interviews were conducted with four male members of the Hungarian Defence Movement (Magyar Önvédelmi Mozgalom). The Hungarian Defence Movement is one of the largest radical right organisations in Hungary. They portray themselves as being a helpful organisation that indeed runs many community-oriented events, all while being heavily anti-Roma. Each interview was about 20-30 minutes long and conducted via telephone call using Skype. Interviews were recorded directly onto a computer and transcribed fully in Hungarian, with only significant quotations translated to English. Provided herein are excerpts from two of the four interviews that are indicative of the argument we are making in this article.

Victimisation was apparent in the rhetoric of the respondents in several ways. The first type of victimisation which was expressed relates to Hungarian history, which is essential to national identity formation. Due to its location in the Carpathian Basin, Hungary was invaded several times throughout history most famously by the Ottomans who conquered the country for over 150 years. In a somewhat revisionist manner, one respondent stated:

Specifically, what they taught us back in grammar school that we were just defeated everywhere, that we were beat everywhere, and that we were slaves, and I don't know what else; this is truly just nonsense. (Respondent 1)

The victimisation expressed in this case is indeed not about the history itself, but about the students in grammar school being betrayed and being fed false information. The most serious form of historical memorialisation in victimisation, however, surrounds the Treaty of Trianon. The treaty was signed in 1920 when the Hungarians separated from the Austrians and republicanised. Because of this, most of the country's lands were lost, leaving hundreds of thousands of ethnic Hungarians living outside of the country's borders. This is still today the most commonly held and strongest attitude among the Hungarian radical right, and provides a strong basis for collective identity formation: "Not one nation in the world has suffered the same fate as the Hungarians did with Trianon" (Respondent 2).

Secondly, and relatedly, there is a perceived victimisation of the Hungarian nation in terms of loss of identity. There seems to be a fear that identity has been lost due to the invasions of foreign cultures throughout Hungary's history: "And at the same time, beside this there is the fact that our national identity, our past, our history, were all 
taken from us" (Respondent 1). This is most especially related to the Hungarians as victims of the Soviets and communism in the $20^{\text {th }}$ century:

What we're living in now is the remains of communism. The communists took everything from us (...) when they were still here after '56, and even before that, they took us down to their level, literally (...) to the level of communism, and I believe we're still living through the last of this. (Respondent 1)

It is clear that there is blame placed on foreign powers, but the nature of the victimisation is unclear. In another statement, Respondent 1 alludes to Hungarians as victims of being seen as foolish: "we aren't a repressed, stupid, idiotic nation like we're made to seem. This is what they did to us; but we're not like this".

Lastly, respondents expressed the victimisation of the Hungarian people by the Roma. Antiziganism is a common attitude among the radical right in Europe, and Hungary has an especially large population of Roma. While it is impossible to accurately state the number of this "hidden" minority through census data, one recent study shows the population of Roma at nearly ten percent of the population of Hungary (Pásztor et al. 2016); this number, however, is about three times as high as what is seen in Hungarian census data, as many Roma do not disclose their minority status (Hablicsek 2008, Pásztor et al. 2016). Ironically, the Roma are the most historically persecuted group in Hungary, with many believing that the Roma are genetically programmed to be criminals. Albeit, many Hungarians, especially those on the radical right, see themselves as the victims of the Roma. In the case of these interviews, it was not actually the victim telling the story, but an outside party recounting events that may or may not have happened. As Respondent 2 recounted:

They came to us and said that the gypsies stole an 82-year-old woman's fence; they even took the fence off the pig-pen. Then they moved the nine-member Roma family in right next door to the 82-year-old lady.

Given the strong national identity of the interviewee, the victim could very well be seen as an extension of their own identity, therefore strengthening the perceived bond between them and the overall feeling of victimisation of the interviewee. This, then, serves to justify further prejudice.

As these interviews have shown, victimisation can aid in collective identity formation. Among the radical right and nationalist rhetoric generally, a nation's history is often revised and reinterpreted. This revision can often occur in a way that places the nation in the role of the victim, providing a basis for collective identity formation, whether real or imagined.

Example two: fleeing Gaza to the UK. The above example illustrates how some groups may use their sense of victimisation to strengthen their collective identity. Another example is offered below to demonstrate further how feelings of victimisation can be employed by individuals to proactively engage their own agency in order to overcome adversity.

The following discussion derives from a research project comparing experiences gathered via face to face interviews with people who had fled conflict to safety with people who had fled conflict and gone on to experience modern slavery. The narrative account discussed below comes from an individual, Oscar (pseudonym), who fled to 
the UK from Gaza, but who did not experience contemporary slavery. The interview was undertaken in English in December 2016. Despite not being a victim of contemporary slavery, it was clear throughout his interview that Oscar did identify himself as a victim in other ways. His account relates to a feeling of victimhood both in the sense of being caught in conflict in Gaza as well as being the victim of a failing asylum system in the UK. His story was chosen because it also demonstrates how he used his own agency to improve his situation in the face of adversity when he realised there was no one else he could rely on for support.

Oscar was living in Gaza in the midst of the fighting. He had previously held a secure job and had worked hard to afford his own home, but because of the conflict, these were taken from him and he had no power to prevent it.

[The war] stopped people from going to school and university, even their normal activities daily. Their jobs, everything, because in that war nobody would dare go out. You stay at home and wait. You don't know where the bombs will be. Sometimes here, there, we don't know. So it was very hard.

He endured a feeling of victimhood because he was now living a life that he had no control over because of a war that he had no say in. His house was destroyed, he had no work and he had to rely on strangers to provide him with food.

I went to my home to bring some things [back to the tent] and I got a call on my landline to say you have to leave your home within five minutes. Leave everything and just go. And I said ok and I did that and in five minutes it was destroyed.

No water, no food. No electricity. No gas, nothing at all. So people who came from like Red Cross who have food for a day, two days, they come every couple of days when they think it's safe to go they'll give us some food and that's it.

Knowing that the situation was unlikely to change, Oscar realised that he had to either accept life the way it now was in Gaza, or find a way to leave the country. It was here that he began to exercise his own agency in the face of adversity by applying for a visa and a travel ticket to leave the country. However, a miscommunication saw Oscar wrongly arrested, where he once again became a victim of a situation that was out of his control.

And that border is (...) only open a couple of days a month or something like that (...). So there's a lot of people who want to leave Gaza for education, for medication, for their reasons. So what they do, the Minister of Interior for Gaza has a waiting list so for example they go to there and they give them a rough date. They're not sure but a rough date. So they make sure that they get the name, the country they want to travel to, the rough date, the bus ticket, the bus number, everything. Even the passport number. And when that border is open, they have a list of people who want to leave Gaza.

So I applied for a visa here and the travel to UK should be soon, only... another three months. So my ticket is not valid at the moment [because the date on the travel ticket does not match the date on the visa]. So I (...) tried to give them my story, I need to exchange this one. And a man was just sitting there. He wants to travel as soon as he can and has a ticket for six months. And I say that's good we can exchange that one. But we cannot just give and take because they have the name and everything. So we are asking to meet the manager or director and he said ok happy to help which is good. But he thought I am selling my ticket for money. 
But he arrested me (...). But they arrested me for 12 days and they took my passport and I'm not allowed to travel. Not allowed to leave Gaza.

Again, Oscar was faced with a decision of accepting the undesirable situation in front of him where he was prohibited from leaving Gaza, or finding another way out. Again, he describes himself as proactively dealing with the situation by refusing to accept the conditions put to him.

So after 12 days I go out with some money for them and even so they say you are not allowed to leave Gaza. But a little bit of money to the people who work there and I got my passport, I pay a lot of money as well to the people who work at the border of Gaza and then I come here [to the UK].

Because Oscar's visa had been revoked with the miscommunication at the border, when he arrived in the UK he was required to apply for asylum. He described how he was granted asylum, given his documents and then told to go, with no information on where he should go or who he could ask for help.

I applied for asylum seeker here and I explained to them in the first interview a little bit about my story. Not all the details because I'm not supposed to do that. And the details what happened in those 12 days, what happened after, it was quite different. And they gave me a document to stay for five years as well. So once I got the document I start my life here. Real life I mean but it's different still. With asylum seeker everything is offered by the Home Office I mean. But once I've got my document from the Home Office, just go. But no accommodation. Do it by yourself. So it's hard.

From my own experience, it's not fair to give people the documents and just leave them. You need at least a couple of months or so just to know you have to do that, you have to do that, you have to do that.

Oscar had previously lived in the UK which meant that his language skills were a huge benefit to him, but because he was offered no support and no information on where he could go for help, he found himself alone. He turned to people he'd known in the UK who offered him limited assistance.

Once I got that document from the Home Office, I visited a friend there [who] said you can stay for a night, two nights but then you have to go. So I was homeless (...). So I had nobody offer me anything.

With no ongoing support from either the UK government or from people he knew, Oscar accepted that there was no one else he could turn to for help and that he needed to find a way to survive by himself.

So I tried my best but I don't get a job. I tried also to get a different job but it wasn't related to my qualification. I was so happy to work with, but no I didn't get that. Oh yeah, I was unemployed when I first came here for about maybe one year.

He described how difficult it was for him being homeless and unemployed, and that the misery caused by those aspects was only compounded by being so far away from his family, especially when he knew they were still in danger from the war in Gaza. He invited his wife and children to come and join him in the UK but told them nothing of the precarious situation he was living in because he was so desperate that they should come to be with him. 
They know nothing about the situation here. They knew nothing that when they came here they'd be homeless like me. And I needed them to come, to help me be not homeless.

Although Oscar had risked putting his wife and children in a vulnerable situation by bringing them to the UK when he had no permanent housing or employment, it was their presence that led to the family receiving the support that Oscar had been in such desperate need of since arriving in the UK. A stranger asked why the family were all sitting on the street and, as a result, Oscar and his family were taken to a local housing office and offered housing in a homeless shelter - something Oscar would have been able to do himself the day he'd been granted asylum if only he'd known that was what was required of him. It was at this point that Oscar felt that his life was finally heading in the right direction and he was able to adapt and become proactive over his life in the UK.

And then I started bidding for a house and I got a house and then I got to start life (...). The house had nothing. And it needed a lot of decorating, a lot of work, so I did that by myself. They didn't give me anything (...) nowadays when people want to go for a house, the housing people give them a voucher so they can decorate. So with this voucher they can buy something. When I went there, nothing.

Oscar's children are now in school, which they were unable to attend in Gaza. His wife is in college, and Oscar works in a homeless shelter supporting people living through situations similar to his own. He had previously wanted to carry on his education and get a $\mathrm{PhD}$, but his experiences as a victim of conflict and being separated from his family changed his priorities.

Well at the moment, life is already very different compared to maybe seven years ago when we'd been in a tent and compared to when we came here, when she came here and we had nothing. So now everything is really done, so it's much better.

Oscar also felt that telling his story was a way of being proactive, that if he told his story it might make a difference to other people's stories. By recounting his experiences, Oscar was placing himself in a situation of power and responsibility where he believed he had a level of control to influence the experiences of others:

I have to [tell my story] because I feel like I have to do something.

Before concluding this discussion it is important to note some caveats about both interviews. Firstly, the interviews are from East Europe and the Middle East. Both are inevitably shaped by their own culture - and these cultures exist, at least to some extent, beyond the late-modern contours developed by West European social theorists. Furthermore, neither example is intended as indicative of how others will have experienced the events they describe, nor are their accounts generalisable in terms of proving the late-modern theoretical framework we deploy.

However, the purpose of drawing on two geographically and culturally different narratives is to reduce any unconscious ethnocentrism in either the social theory or the assumptions we might inadvertently make. By stepping outside of conventional forms of criminal victimisation we seek to stretch the traditional criminological frame of reference and engage with types of grievance more typically found in large-scale human rights violations. These interviews are therefore intended to provide concrete examples of a theoretical position we have developed that victim story-telling is not 
just an important part of reconstructing self-identity it is also a new form of selfmemorialising that provides resilience through the process of narrative construction.

\section{Story-telling, memorialisation and resilience}

Both the Hungarian and Gaza interviews provide good examples of how people construct their stories of victimhood in ways that demonstrate a sense of identity and agency over the circumstances of their, real or perceived, suffering. Of course, an interview is just another style of story-telling, but these examples show some of the strategies that support our wider discussion of the importance of story-telling as a type of memorialisation.

Our interest is therefore in the process of memorialising victim stories. How and why are stories told and recorded? And what purpose do they serve for victims of largescale human rights violations? We have tried to capture the cultural drivers that shape the meaning and opportunity for story-telling and how narrative can provide a sense of agency and control over the fraught realities of late modern existence (Green and Pemberton 2017). This agency and control can also be understood as strategies for resilience - a way of coping or even transforming oneself in response to suffering and harm. The process of memorialising victim stories therefore seems to contain several stages, beginning with reaction to the event, followed by a period of reflection and then reconstruction of events that are then ritualised through the telling, retelling and recording of the stories by both individuals and groups. This process provides agency and control which can be understood as a type of resilience.

The below diagram is an attempt to represent this process of memorialisation and resilience by co-ordinating the different elements we have identified within the cultural conditions of late-modernity. In 2013, Sandra Walklate (2013) created an axis of resilience which maps out the relationship between adversity and risk. This axis provides a strong visual representation of vulnerability and resilience and is a development of an earlier axis of vulnerability produced by Green (2007). For the sake of clarity, the below diagram is separate from both and intended to represent resilience through memorialisation. The dynamics and reference points are therefore entirely different. Both Walklate (2013) and Green's (2007) axes are constructed in relation to socio-economic conditions and risk; the below diagram is constructed in relation to the development of resilience through a process of memorialising harm and violation. 


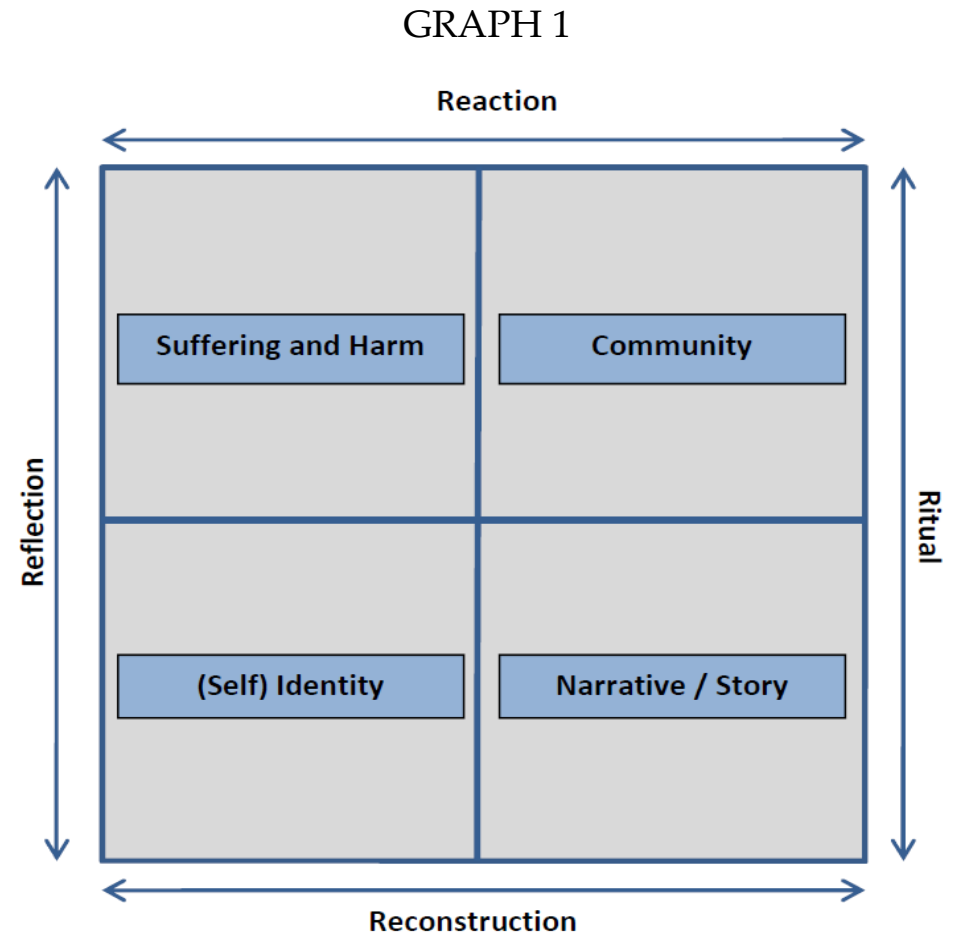

Graph 1. Square of Memorialisation and Resilience.

This diagram is intended to represent the continuous process by which victims achieve resilience through memorialisation. There is no overt chronology to this process as it is ongoing with no definitive start or end point. However, "Reaction" is the most logical start point, though different reactions may be felt at later stages in the process. We have therefore opted for a model devoid of any chronological order on the grounds that the four behaviours may overlap and change simultaneously, meaning that each will interact with the other rather than follow from it. The four sides of the square can be understood as follows:

1. Reaction: the victim reacts to the suffering and harm inflicted on them and the related reaction from their community.

2. Reflection: the victim strives to make sense of their suffering and harm and how it affects their sense of (self) identity.

3. Reconstruction: the victim shapes and reshapes the suffering and harm around their sense of (self) identity and how they construct their story.

4. Ritual: the victim shares their story with others and, through a process of telling and retelling, ritualises the suffering and harm and their role in responding to it. This may generate new reactions, reflections and reconstructions which in turn alter the story and therefore the ritualisation of it.

This ongoing process provides a sense of control and agency for the victim, allowing them to adapt over time if their environment or circumstances change. Similarly, it provides a basis for connection to others and the formulation of a sense of belonging, or community. The implication of this model is that an ongoing process of memorialising through story-telling provides the basis for agency, control and belonging for the victim which in turn provides the foundations of resilience. 


\section{Conclusion: the cultural conditions of memorialisation}

Memorialisation is often thought about in terms of physical structures such as memorials, cenotaphs, exhibitions or museums. We have attempted to demonstrate that story-telling can also be understood as a type of memorialisation for the victims of crime and large-scale human rights violations. The cultural conditions of late modernity create insecurity, instability and anxiety which, when coupled with crime and violation, form a perfect storm in which crime victims experience a "doublewhammy" from cultural and personal circumstances. One way in which victims react to these circumstances is by telling and retelling their stories in ways that give them a sense of agency and control over them. We have shown how this process fits within social theory, cultural conditions and formal and informal victim testimony. Drawing on two examples from different cultural contexts, we have explored how people can construct their own narratives of harm and victimisation in such a way that provides a sense of self-identity, belonging and purpose. These narratives contain personal, historical and political testimonies that are part of the process of coping with trauma and generating meaning for the privations experienced. These voices informed the development of the square of memorialisation and resilience which is intended to demonstrate the interactional dynamics that give meaning to the process by which story-telling plays a role in the reconstruction of self-identity in the aftermath of crime and large-scale human rights violations.

The purpose of our discussion has been to draw attention to the importance that storytelling can have in helping victims cope with, and even transform their lives following harm and suffering. A secondary purpose has been to identify the cultural dynamics that provide meaning and shape to these narratives which in turn help to understand the growing importance of victim voices within both criminal justice and public life more widely. By explicitly identifying the importance and potential of story-telling as part of a process through which victims can exercise a degree of agency and control, we hope to draw attention to victim narratives as both a route for capturing their voices in new and emerging forms of memorialisation and new directions in victimological research.

\section{References}

Antze, P., and Lambek, M., eds., 1996. Tense Past: Cultural Essays in Trauma and Memory. London: Routledge.

Aslama, M., and Pantti, M., 2008. Talking Alone: Reality TV, emotions and authenticity. In: M. Greco and P. Stenner, eds., Emotions: A Social Science Reader. London: Routledge, pp. 339-346.

Barbot, J., and Dodier, N., 2014. Rethinking the role of victims in criminal prosecution: The normative repertoire of lawyers in France and the United States. [Translated from French by S.L. Raillard]. Revue française de science politique [online], 64(3), 407-434. Available from: https://www.cairn-int.info/article-E RFSP 643 0407-rethinking-the-role-of-victims-in.htm [Accessed 13 February 2020]. (Originally published in French: Repenser la place des victimes au procès pénal: Le répertoire normatif des juristes en France et aux États-Unis, available from: https://doi.org/10.3917/rfsp.643.0407 [Accessed 13 February 2020]). 
Beck, U., 1992. Risk Society: Towards a New Modernity. London: Sage.

Beck, U., 1994. The Reinvention of Politics: Towards a Theory of Reflexive Modernisation. In: U. Beck, A. Giddens and S. Lash, eds., Reflexive Modernisation: Politics, Tradition and Aesthetics in the Modern Social Order. Cambridge: Polity Press.

Brison, S., 2002. Aftermath: Violence and the Remaking of a Self. Princeton University Press.

Cuéllar, A.C., ed., 2013. Memories and Violence: Problems and Debates in a Global Perspective. Dubai: Zayed University Press.

de Gaulejac, V., and Legrand, M., eds., 2008. Intervenir par le récit de vie. Toulouse: Erès.

de Haan, W., and Loader, I. 2002. On Emotions of Crime, Punishment and Social Control, Theoretical Criminology [online], 6(3), 243-253. Available from: https://doi.org/10.1177/136248060200600301 [Accessed 13 February 2020].

Dubet, F., 2002. Le déclin de l'institution. Paris: Le Seuil.

Durkheim, E., 1964. The Division of Labor in Society. Trans.: G. Simpson. New York: The Free Press. (Originally published in 1893).

Fassin, D., 2014. De l'invention du traumatisme à la reconnaissance des victimes. Genèse et transformations d'une condition morale. Vingtième Siècle. Revue d'histoire [online], no 123, pp. 161-171. Available from: https://doi.org/10.3917/vin.123.0161 [Accessed 13 February 2020].

Fassin, D., and Rechtman, R., 2009. The Empire of Trauma: An Inquiry into the Condition of Victimhood. Trans.: R. Gomme. Princeton University Press.

Furedi, F., 2004. Therapy Culture: Cultivating Vulnerability in an Uncertain Age. London: Routledge.

Garapon, A., and Denouveaux, A., 2019. Victimes, et après? Paris: Gallimard.

Garland, D., 2000. The Culture of High Crime Societies: some preconditions of recent "law and order" policies. British Journal of Criminology [online], 40(3), 347-375. Available from: https://doi.org/10.1093/bjc/40.3.347 [Accessed 13 February 2020].

Garland, D., 2001. The Culture of Control: Crime and Social Order in Contemporary Society [online]. Oxford University Press. Available from: https://doi.org/10.7208/chicago/9780226190174.001.0001 [Accessed 13 February 2020].

Gatti, G., ed., 2017. Un mundo de víctimas. Barcelona: Anthropos.

Gensburger, S., and Lefranc, S., 2020. Beyond Memory: Can We Really Learn from the Past? London: Palgrave Macmillan.

Giddens, A., 1990. The Consequences of Modernity. Cambridge: Polity Press.

Giddens, A., 1991. Modernity and Self Identity: Self and Society in the Late Modern Age. Cambridge: Polity Press.

Giddens, A., 1992. The Transformation of Intimacy. Cambridge: Polity Press. 
Giddens, A., 1994. Living in a Post-traditional Society. In: U. Beck, A. Giddens and S. Lash, eds., Reflexive Modernisation: Politics, Tradition and Aesthetics in the Modern Social Order. Cambridge: Polity Press.

Green, S. 2007. Crime, Victimisation and Vulnerability. In: S. Walklate, ed., Handbook of Victims and Victimology. Cullompton: Willan, pp. 91-120.

Green, S., 2011. Vengeance and Furies: existential dilemmas in penal decision-making. In: R. Lippens and J. Hardie-Bick, eds., Crime, Governance and Existential Predicaments [online]. Basingstoke: Palgrave MacMillan, pp. 61-84. Available from: https://doi.org/10.1057/9780230343184 4 [Accessed 13 February 2020].

Greer, C., 2004. Crime, Media and Community: Grief and Virtual Engagement in Late Modernity. In: J. Ferrell et al., eds., Cultural Criminology Unleashed. London: Glasshouse Press, pp. 109-121.

Hablicsek, L., 2008. The development and the spatial characteristics of the Roma population in Hungary: Experimental population projections till 2021. Demográfia [online], 51(5), 85-123. Available from:

https://ideas.repec.org/a/nki/journl/v51y2008i5p85-123.html [Accessed 13 February 2020].

Herman, J., 2015. Trauma and Recovery (with a new Epilogue by the Author). $1^{\text {st }}$ revised ed. New York: Basic Books.

Holloway, M., Hukelova, M., and Bailey, L., 2018. RememberMe: Memorialisation in Contemporary Society [online]. University of Hull. Available from:

https://remembermeproject.files.wordpress.com/2018/06/displaying-self-finalreport-epublication.pdf [Accessed 13 February 2020].

Jasper, J.M., 1997. The Art of Moral Protest: Culture, Biography, and Creativity in Social Movements [online]. University of Chicago Press. Available from: https://doi.org/10.7208/chicago/9780226394961.001.0001 [Accessed 13 February 2020].

Jasper, J.M., and McGarry, A., 2015. Introduction: the identity dilemma, social movements, and contested identity. In: A. McGarry and J. Jasper, eds., The Identity Dilemma: Social Movements and Collective Identity [online]. Philadelphia: Temple University Press, pp. 1-17. Available from: https://doi.org/10.2307/j.ctvrdf3v5.4 [Accessed 13 February 2020].

Karstedt, S., 2002. Emotions and Criminal Justice, Theoretical Criminology [online], 6(3), 299-317. Available from: https://doi.org/10.1177/136248060200600304 [Accessed 13 February 2020].

Kumar, K. 1978. Prophecy and Progress: The Sociology of Industrial and Post-Industrial Society. Harmondsworth: Penguin Books.

Lash, S., 1994. Reflexivity and its Doubles: Structure, Aesthetics, Community. In: U. Beck, A. Giddens and S. Lash, eds., Reflexive Modernisation: Politics, Tradition and Aesthetics in the Modern Social Order. Cambridge: Polity Press, pp. 110-173. 
Lefranc, S., 2015. La justice de l'après-conflit politique: justice pour les victimes, justice sans tiers ? Négociations [online], 2(24), pp. 101-116. Available from: https://doi.org/10.3917/neg.024.0101 [Accessed 13 February 2020].

Martuccelli, D., 2010. La société singulariste. Paris: Armand Colin, coll. Individu et société.

Marx, K., (with F. Engels, ed.), 1970. Capital, vol. 1. London: Lawrence \& Wishart. (Originally published in 1861).

Mawby, R.I., and Walklate, S., 1994. Critical Victimology [online]. London: Sage. Available from: http://dx.doi.org/10.4135/9781446250587 [Accessed 13 February 2020].

McGarry, R., and Walklate, S., 2015. Victims: Trauma, Testimony and Justice [online]. London: Routledge. Available from: https://doi.org/10.4324/9780203727379 [Accessed 13 February 2020].

Morgan, C., and Averill, J.R., 2008. True feelings, the self, and authenticity: A psychosocial perspective. In: M. Greco and P. Stenner, eds., Emotions: A Social Science Reader. London: Routledge.

Pásztor, I.Z., et al., 2016. The number and spatial distribution of the Roma population in Hungary - in the light of different approaches. Folia Geographica [online], 58(2), 521. Available from: https://www.unipo.sk/public/media/26990/1THE\%20NUMBER\%20AND\%20SPATIAL\%20DISTRIBUTION\%20OF\%20THE\%2 OROMA \%20POPULATION\%20IN\%20HUNGARY\%20\%e2\%80\%93\%20IN\%20TH E\%20LIGHT\%20OF\%20DIFFERENT\%20APPROACHES.pdf [Accessed 13 February 2020].

Peris Blanes, J., 2005. La imposible voz: Memoria y representación de los campos de concentración en Chile: la posición del testigo. Santiago de Chile: Cuarto Propio.

Shapland, J., Willmore, J., and Duff, P., 1985. Victims of Crime in the Criminal Justice System. Aldershot: Gower.

Skultans, V., 1998. The Testimony of Lives: Narrative and Memory in Post-Soviet Latvia [online]. London: Routledge. Available from: https://doi.org/10.4324/9780203445013 [Accessed 13 February 2020].

Snow, D.A., 2001. Collective identity and expressive forms. In: N. Smelser and P.D. Baltes, eds., International Encyclopedia of the Social and Behavioral Sciences [online]. New York: Elsevier, pp. 212-219. Available from: https://doi.org/10.1016/B0-08043076-7/04094-8 [Accessed 13 February 2020].

Walklate, S., 2013. Reframing criminal victimization: Finding a place for vulnerability and resilience. Theoretical Criminology [online], 15(2), 179-194. Available from: https://doi.org/10.1177/1362480610383452 [Accessed 13 February 2020].

Weber, M., 1976. The Protestant Ethic and the Spirit of Capitalism. London: Allen \& Unwin. (Originally published in 1904-5).

Wieviorka, M., 2009. Violence: A New Approach [online]. London: Sage. Available from: http://dx.doi.org/10.4135/9781446269589 [Accessed 13 February 2020]. 